\title{
PATENT, TECHNOLOGY, AND THE ROLE OF UNIVERSITY
}

\author{
Agus Sardjono ${ }^{1}$
}

\begin{abstract}
:
University has significant contribution to the development of nanotechnology. The role of university can be implemented through the TTLO, particularly in an effort to build a bridge for bottom-up nanotechnology for commercial purposes. There will be an increasingly significant link between the patent system and the university role in the development of nanotechnology.
\end{abstract}

\section{Introduction}

As of February 11, 2010, the US Patent and Trademark Office (USPTO) had classified 5,909 patents into class $977^{2}$ as patents in the field of nanotechnology. ${ }^{3}$ One may wonder, what is the relevance of this to us? Indeed, although it may not be directly relevant for us, this data at least indicate that the development of nanotechnology has produced many new innovations with the potential of application in commercial industry.

This leads us to the next question, namely, what is the relevance of this to the role of University? At the least, this role becomes evident in connection with one of the functions of university as an institution responsible for education and research. In other words, university has significant contribution to the development of nanotechnology.

Have Indonesian universities been able to provide significant contribution to the development of nanotechnology? Have Indonesian universities been able to come up with inventions in the field of nanotechnology? The answer to this questions lie in the hearts of research, members of the civitas academica in their respective universities. The subject of this article is not a discussion on the achievements of certain universities in the area of nanotechnology, rather it will focus on patents and their relation to the development of nanotechnology, as well as the role that universities can play in this particular aspect.

\section{Patent, a legal protection regime}

Patent is a widely misunderstood term. In Indonesian there are many expressions using the word patent with many different connotations, which are often not even close to its original meaning. For example, people would often say "waah obatnya paten banget" (wow, this medicine is so effectual), using the word 'paten' (effectual) as adjective, which implies the quality of being highly effective and reliable.

\footnotetext{
${ }^{1}$ Professor of Law at Faculty of Law University of Indonesia

${ }^{2}$ Patent Classification is classification of invention that can be granted with patent right based on the laws and regulations in the field of Patents.

3 J. Steven Rutt, <http://www.nanotechblog.com/2010/02/articles/patent/recent-nanotechpatent-trends-top-ten-observations/>, accessed on February 12, 2011.
} 
Another commonly used expression is "apakah mereknya sudah dipatenkan?" (has the trade mark been patented), or "waduh, tutup ini tidak bisa lepas, mungkin sudah paten" (alas, this cover cannot be removed, maybe it has been made fixed). These everyday expressions indicate people using them may not be fully aware of the actual meaning of the word "patent".

From the etymological point of view, the word 'patent' is the antonym of the word 'latent.' 'Latent' means 'hidden, concealed', while 'patent' means 'open'. ${ }^{4}$ From the terminological point of view, the latter was subsequently used to denote a legal institution in the form of a right, which is indeed related to the transparency of information.

In simple terms, patent can be defined as a right in the form of legal protection enjoyed by inventor who is prepared to disclose information to the public related to his or her invention in the field of technology. It can be also said that patent is a reward to an inventor who is prepared to share information about his or her invention in the field of technology.

Who grants such reward? The answer to this question can be found in Law Number 14 Year 2011 Concerning Patents (hereinafter shall be referred to as the Patent Law of 2001) ${ }^{5}$ stating that patent is a right granted by the state to an inventor who applies for patent protection right. ${ }^{6}$ This is provided for in Article paragraph (1) as follows:

"Patent is an exclusive right granted by the state to an inventor for his invention in the field of technology, for a certain period of time to implement his or her own invention or grant his or her approval to another party to implement the same." 7

Notably, the abovementioned provision does not explicitly provide for a reward. However, through a careful reading, it is obvious that as part of the procedure prior to obtaining the patent, an inventor is required to explain his or her invention in the document containing patent description, which is a prerequisite for obtaining the patent right concerned. Such patent description is then announced to the public (laying open for public) in the process of right application. ${ }^{8}$ The document is available

\footnotetext{
${ }^{4}$ For the history of the word 'patent' (literae patentes) refer to William Aldous, et. al., The Law of Patent, (London: Sweet \& Maxwell, 1982), p. 1.

${ }^{5}$ The currently applicable law in Indonesia is Law Number 14 Year 2011 Concerning Patents [State Gazette of the Republic of Indonesia Year 2001 No. 109]. (Hereinafter to be briefly referred to as the Patent Law of 2001). This law is an adjustment or Indonesia's compliance following the ratification of the Agreement on the Establishment of the World Trade Organization, which includes among other things the agreement on trade related intellectual property rights known as the TRIPs Agreement (Agreement on Trade-related Aspects of Intellectual Property Rights), Ratification was enacted in Law Number 7 Year 1994.

${ }^{6}$ The provision in the said Patent Law is a continuation of the history of patent. It started in the middle ages at a time when England was not yet technologically developed. Merchants from Venice came to England bringing merchandise that had been unknown in England at the time. In the course of trading in such merchandise, British merchants became interested in producing the same, however they did not possess the requisite knowledge/technology. They asked the merchants from Venice to disclose to them the technology required. See, Aldous, et. al., The Law of Patent, p. 1.

${ }^{7}$ The original text in Indonesian reads as follows: "Paten adalah hak ekslusif yang diberikan oleh Negara kepada Inventor atas hasil invensinya id bidang teknologi, yang untuk selama waktu tertentu melaksanakan sendiri invensinya tersebut atau memberikan persetuuannya kepada pihak lain untuk melaksanakannya."

${ }^{8}$ Using Japan Patent Law as comparison [note: it would be better to describe the comparison here.]
} 
to the public, enabling anyone to examine or research the relevant technology. ${ }^{9}$ Only after such public announcement procedure the State could learn the innovativeness of such application and will grant reward in the form of exclusive right protection to the inventor concerned.

The purpose of the disclosure is to enable any interested party to study such information. ${ }^{10}$ This is origin of the word patent. In the fifteenth century, Venetian merchants arrived at the British soil bringing new technology. These merchants were already familiar with the monopoly system in using technology, even though at that time it was not known as 'patent'. ${ }^{11}$ In order to securing the use of knowledge about the technology contained in their merchandise, they requested the King to grant them to monopoly right on using the relevant technology within British territory. They conveyed such request when the King asked them to disclose information and teach the relevant technology to the locals. ${ }^{12}$ Latter such a request, is known as patent protection system, namely protection granted by the State (King) to inventors in the field of technology who were prepared to disclose information about the technology concerned. Thus, it can also be concluded that in fact patent is an institution which became the primary instrument for transfer of technology related activities.

In the course of its further development, patent became a highly important instrument in commerce, particularly in trade with Intellectual Property Rights aspects. This has been duly documented in the Agreement on the Trade-related aspect

${ }^{9}$ The is one of the full disclosure principle in the patent protection system uniformly applicable in all WTO member states in the world. Moreover, this document can be accessed in all States in the world due to the patent information system available at the Patent Offices of TRIPs member states. At the time of conducting research in Japan at the Japan Patent Office in Tokyo, the author had the opportunity to witness the enormous number of members of the Japanese community using this patent information system, which is available at the Japan Patent Office.

10 This is the essence of the patent protection system. The issue is that not all nations in various States have the same ethos of creativity and creation. In some countries, such as Japan, the United States of America, and Europe, whose societies have a tendency of awarding creativity and self-development based on such creativity, patent system-based technological development is ideal. On the other hand, in countries whose societies have a greater inclination towards imitation, a hedonistic way of life and a lazy attitude, the patent system does not provide meaningful support to technological development in the country concerned. Although admittedly this opinion requires further proof, based on the number of patent Applications in Indonesia, it would appear that patent protection in Indonesia has not become a motivating factor to members of the community for using the patent system in creating and working in technological development based on such individual creativity.

11 Following is an excerpt from the translation of the Venetian Statue 1471 as quoted from Jill McKeough, et. al., Intellectual Property: Commentary and Materials, $4^{\text {th }}$ ed., (Lawbook C., 2007), p. 304 - 305, which reads as follows: "Be it enacted that, by the authority of this Council, every person who shall build any new and ingenious device in this City (Venice - pen), not previously made in our Commonwealth, shall give notice to the office of our General Welfare Board when it has been reduced to perfection so that it can be used and operated. It is forbidden to every other person in any of our territories and towns to make any further device conforming with and similar to said one, without the consent and license of the author, for the term of 10 years. And if anybody builds it violation hereof, the aforesaid author and inventor shall be entitled to have him summoned before any magistrate of the City, by which magistrate the said infringer shall be constrained to pay him hundred ducats; and the device shall be destroyed at once. It being, however, within the power and discretion of the Government, in its activities, to take and use any such device and instrument, with the condition however that no one the author shall operate it."

12 See Hulme, "The History of the Patent System Under the Prerogative and at Common Law" (1986), as quoted in McKeough, Intellectual Property, p. 305. 
of Intellectual Property Rights (TRIPs Agreement), which became an important Annex to the Agreement Establishing World Trade Organization (WTO).

Through the TRIPs system, patent has become what can be described as a uniform international legal regime. This has been due to the fact that through the TRIPs Agreement, all member States are required to adjust their national laws to the legal norms adopted in the TRIPs Agreement. Therefore, speaking about patent regulation in Indonesia will have the same implications as patent regulation in Japan, China, Europe, the U.S., Australia, South Africa, and so forth. Naturally, there are occasional differences; however, such differences will never be related to the substantive matters.

\section{Some important issues related to the patent system}

\section{A. Protection System}

For researchers intending to commercialize their invention in industry, patent is an alternative protection for the application of the technology concerned. It helps avoiding risks related to unauthorized use of the inventors' technology. In accordance with the basic idea that the patent system grants award to an inventor who is prepared to disclose the technology concerned, such reward is granted by the State to an inventor for the exclusive use of his or her technology over a certain period. ${ }^{13}$

The time and manner in which the State provides legal protection to an inventor is determined by the inventor himself. In order to obtain protection from the State, an inventor must take an active approach in seeking such protection. Thus the patent protection system is known as an active protection system or positive protection system. ${ }^{14}$

An inventor who wishes to obtain patent protection has to submit an application for protection to the State through the local Patent Office. ${ }^{15}$ Such application must be accompanied by documents containing information on the technology concerned. This is in accordance with the meaning of the word 'patent' which means open, therefore, in order to obtain protection the inventor must first of all disclose information on the invention concerned. In practice, such information can be disclosed in documents commonly referred to under the following terms: patent specification, patent description, and the like. Such

${ }^{13}$ In the TRIPs Agreement, such period of time is 20 years as from the filling date at the IPR Office at which the application for protection is filed.

${ }^{14}$ For a better understanding of the active or positive protection system, it can be compared to the passive protection system of Copyright. It is referred to as passive, because the Author does not have to take an active part in seeking protection from the State. Copyright protection comes into existence automatically as soon as a piece of work is completed.

15 The term Patent Office is used in many different ways in different countries. In Japan it is called the Japan Patent Office (JPO), in the U.S. it is referred as the United States Patent \& Trademark Office (USPTO), in Europe it is called the European Patent Office (EPO). In Indonesia, it has a slightly different name, namely the Directorate General of Intellectual Property Rights (DG-IPR), which includes the Directorate for Patent (Direktorat Paten). 
documents describe the manner in which the technology concerned is applied in the production process, enabling the practice of invention. ${ }^{16}$

In practice, not all people possess the requisite skills to put together a patent description. Even a law graduate who as a thorough understanding of patent laws and regulations may not be able to compose a suitable patent description. That is why this document is usually prepared jointly by the inventor, who understands the technology of his invention, and a patent consultant who has the expertise in spelling out the description of the technology as required in the patent application form. ${ }^{17}$

Admittedly, obtaining patent protection entails a relatively long process. There are certain stages to be completed before the State grants to an inventor patent protection. First, the inventor must submit an application for registration, which must be accompanied by the following supporting documents, among other things:

1) Information on the applicant's domicile. This document is required as evidence of the completeness of the applicant's address as provided for under paragraph (2.b) Article 24 of the Patent Law of 2011;

2) Evidence on the inventor's nationality. This document is required as evidence of the inventor's full name and nationality, as set forth in paragraph (2.c) Article 24 of the Patent Law of 2001. This requirement is needed considering the fact that patent has become an almost universally applicable protection system, whereby inventors can apply for patent protection in many different countries, depending on the place of the targeted commercial exploitation of the invention concerned. Therefore inventors from Japan can apply for patent protection in Indonesia;

3) Information on the Patent Consultant that represents the inventor in the application process. This document is to prove that the Patent Consultant is an authorized IPR consultant according to Indonesian law. This legal basis for this is the provision of paragraph (2.e) Article 24 of the Patent Law of 2001 and the Government Regulation No. 2 Year 2005 concerning IPR Consultants, particularly Article 5;

4) Statement on the application for obtaining patent protection. The provision of Article 24 of the Patent Law of 001 paragraph (2.f) requires that this statement must be included in application for obtaining patent protection;

5) The application must state the title of invention and the claim in the invention for which protection is being sought. Information on the title of the invention and the claim among with the abstract of the same are usually included in the document containing patent specification and patent description. This requirement is based on paragraph (2.h.i.j.k)

${ }^{16}$ See Article 24 paragraph (2.i) of the 2001 Patent Law. See also Robert Patrick Merges, Patent Law and Policy: Cases and Materials.(Virginia, Michie, 1992) pgs. 657 -668. This book describes the manner in which disclosure and enablement are applied based on Patent Law in the U.S.

17 This work is usually done by a Patent Attorney or a Patent Consultant appointed by the inventor to represent him in the process of filing at the Patent Office. 
Article 24 of the Patent Law of 2001. It is normally in the stage of preparing the claim, description, drawings, and the abstract that a Patent Consultant is involved in each respective country.

This application process requires a relatively long period of time. This is due to the various stages that need to be completed, including among other things: laying open for public, substantive examination to establish the patentability of the invention concerned, objection (if required), and so forth, as provided for in Chapters III and IV of the Patent Law of 2001 (Articles 20 to 65). Obviously the inventor or applicant seeking protection should have a lot of patience during the whole process.

In addition to the documentation and the time consuming process required for patent registration application, inventors also need to consider the cost related to such registration as well as the annual fee ${ }^{18}$ which must be paid for twenty consecutive years if the inventors wish to have protection from the State. The high cost of patent registration and of maintaining a patent must serve as a basis for IPR valuation and management by those wishing to obtain patent protection. If the commercial value of the invention is significant compared to the costs that need to be incurred related obtaining the intended legal protection, commercial value is relatively small compared to the costs, patent may not be the appropriate regime for protection. Trade secret may be considered as an alternative protection. ${ }^{19}$

This may be somewhat dilemmatic for university researchers, particularly when it is not yet possible to calculate the costs due to lack of a clearly defined IPR valuation and management system at the university concerned. It is obvious however, that to university researchers at the patent protection system requires a relatively large amount of funding. Patent applications for inventions originating from universities should be considered in the light of the marketability of the invention concerned.

\section{B. Subject Matter of Protection}

The subject matter of patent protection is the right to use the invention in the field of technology. That is why patent as part of IPR is considered to be an intangible asset, because it is a right, rather than a product or process.

In order to understand this, it may be opportune to mention a little bit more about the history of patent. When the King of England asked the Venetian merchants to teach his people to produce the merchandise in England, the merchants requested in return monopoly right for trading the goods concerned in British territory. The King accepted such proposal by granting them the monopoly right they had requested. That is patent as we know it today.

Thus, protection is provided not for the technology, nor the goods, rather for the inventor's right to use the technology concerned to produce and trade

${ }^{18}$ Refer to Article 114 of the 2001 Patent Law.

19 Trade Secret is an IPR system provided for under IPR laws and regulations which can be used by inventors in the field of technology who do not wish to use the patent system. However, the Trade Secret regime also entails protection requirement for those wishing to obtain protection. 
goods produced based on the technology. That is the reason why it is referred to as intangible assets, because it is in the form of the right to monopolize, or more elegantly referred to as an exclusive right. ${ }^{20}$

In order to facilitate the patent information system which in turn is to be used prior to art search and patent registration, various types of invention are classified into groups referred to as patent classification. The Strasbourg Agreement is concluded to provide the patent classification system. ${ }^{21}$ Based on this agreement, patentable inventions are classified in to section, subsection, class, group, etc. Pursuant to this agreement, inventions are classified into 8 Sections as follows:

a. Human Necessities

b. Performing Operations; Transporting

c. Chemistry; Metallurgy

d. Textiles; Paper

e. Fixed Constructions

f. Mechanical Engineering; Lighting; heating; Weapons; Blasting

g. Physics

h. Electricity

These sections are further broken down into sub-sections, which are further divided into sub-sub sections. For example, the Human Necessities section is divided into the following sub-sections: Agriculture, Foodstuffs, Personal or Domestic Articles, Health, Amusement. Furthermore, this sub-section is further broken down into class and group, and then numbers are assigned to it in order to facilitate identification. For example, Electricity is given the code $\mathrm{H}$, and the sub-sections and groups under it also marked with numbers, as evident in the following example:

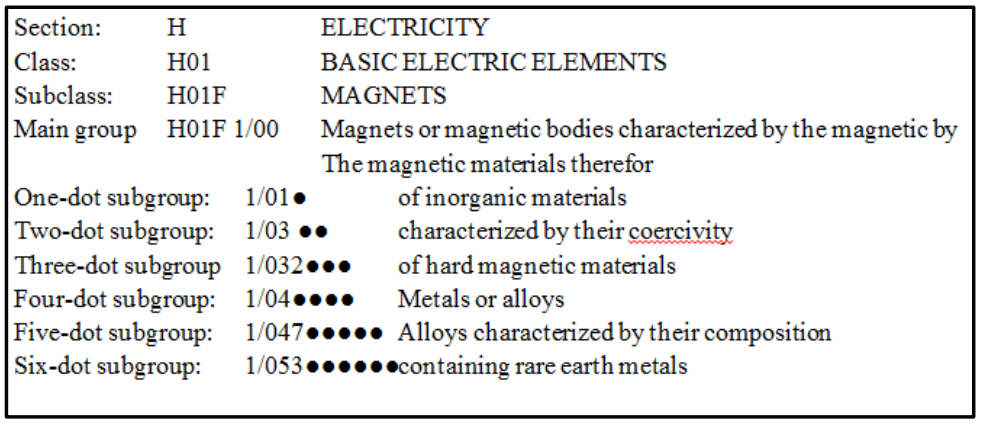

${ }^{20}$ Article 1 sub-article (1) of the 2001 Patent Law affirms as follows: "patent is an exclusive right granted by the State to the Inventor for his or her invention in the field of technology ..."

${ }^{21}$ Refer to The Strassbourg Agreement concerning The International Patent Classification 1971 which entered into force on October 7, 1975. This agreement has been subject to constant revision or improvement, most recently in 2006 and subsequently referred to as the Eight Edition 2006. Indonesia has not yet ratified this agreement. In practice at the Patent Office, however, the classification based on this agreement has already been in effect. Similar has also been the case with the Mark classification adopted under the Nice Agreement; although Indonesia has not yet ratified it, Indonesia has been using this Mark classification. 
The above described classification makes it easier for researchers to study patentable technology and patented technology. This will is extremely useful for research at universities, particularly for avoiding duplication in research. By conduction prior art search through the patent information system and patent classification, researchers are able to access information on the technology to be researched or that is being researched. A researcher interested to apply for a patent for his invention must also take into account the patentability requirement for the invention concerned. Following is a description of such requirements.

\section{Protection requirements (patentability of invention)}

In order for an invention to be patentable, it has to meet certain requirements prescribed by the law. ${ }^{22}$ This is quite logical, considering that patent is a reward to the inventor who is prepared to disclose information on the technology concerned. Naturally, not all disclosure of invention is eligible for a reward in the reform of patent. Only new or novel inventions and those containing inventive, non-obvious procedures, as well as industrially applicable inventions are eligible for protection. ${ }^{23}$

' $N e w$ ' is not intended to imply something that was never there before, and it has now come into being or something old being renewed. Under the patent protection system, new or novel has a very technical meaning: something that had never published prior to the filing date. ${ }^{24}$ This provision is of highly technical nature, and not all people understand what it exactly means.

Consequently, a genuinely new invention may in fact be non-patentable because its inventor, unfamiliar with the patent protection system, publishes the technology concerned prior to filing for a patent. In other words, genuinely new inventions are in fact not considered to be novel by the patent regulation. ${ }^{25}$ On the other hand, a technology which is not new may be considered new just because the patent examiner does not find any documents indicating the technology concerned has existed previously. ${ }^{26}$

22 This in the line with the positive patent protection system, whereby of course not all inventions are eligible for patent application. The law sets forth the requirements for inventions for which the State can grant a reward in the form of protection for their inventors.

${ }^{23}$ This requirement is uniformly applicable in all States that are signatories to the World Trade Organization (WTO), because one of the agreements is related to the Trade-related aspects of Intellectual Property Rights. Article 27 of TRIPs Agreement reads as follows: "patent shall be available for any inventions, whether products or process, in all fields of technology, provided that they are new, involve an inventive step and are capable of industrial application".

${ }^{24}$ Article 3 paragraph (1) of the 2001 Patent Law reads as follows: "an invention is considered to be new if on the date of receipt, the invention is not identical to a previously disclosed technology". The key word "disclose" in this article implies that the invention concerned has never been published in Indonesia or outside of Indonesia in writing, verbally, or through demonstration, or in any other manner that would enable an expert to implement such invention [Article 3 paragraph (2)]. The basic question is: "did someone else publish the same idea earlier?". See Merges, Patent Law and Policy, p. 223.

25 This occurred in the case of patent application of 'Sosrobahu' technology.

${ }^{26}$ Reportedly, a design patent taken from a wood carving sold long before in Bali was registered at the USPTO. Only because the U.S. patent examiner was unable to find a document indicating that the technology concerned had previously existed in another country, they decided to grant patent for an invention that was actually not new. In this case, the examiner's subjectivity was way too dominant in 
The next requirement for an invention to be patentable is non-obviousness. AN invention is considered to be non-obvious if it was previously non-obvious to a person having ordinary skill in the area of the technology related to the invention. ${ }^{27}$

The category of "non-predictable" does not necessarily mean something sophisticated. Even the simplest technology applied in a toothpick has obtained patent protection in Japan. Who would think that these two objects are granted patents?

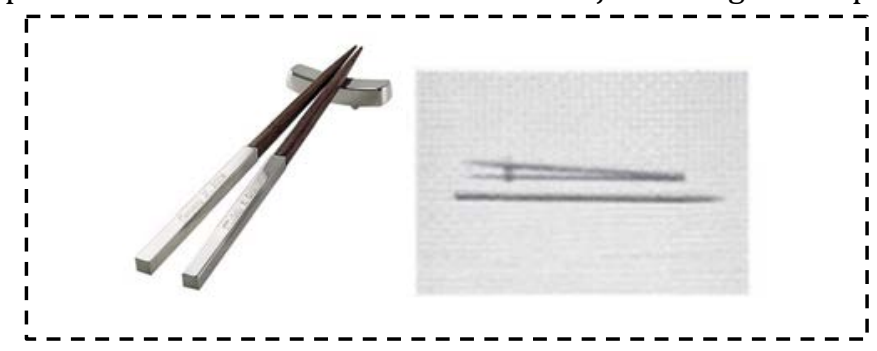

According to J. Whiterspoon, non-obviousness is the ultimate condition of patentability. ${ }^{28}$ This is quite understandable, considering that non-obviousness is the criteria for determining the novelty quality of an invention.

In simple terms it can be stated that a technology with a high level of nonobviousness is an indication that is a new technology. Thus, novelty and nonobviousness constitute a complementary pair of values.

Another requirement for an invention's patentability is usefulness. The word 'useful' refers to the possibility that in addition to having utility value, ${ }^{29}$ the invention concerned can also be implemented in a production process or industry. This is asserted in Article 5 of the Patent Law of 2001, which reads as follows: "An invention can be applied in the industry if such invention can implemented in industry concerned as described in the application." This provision is a further elaboration on the disclosure requirement for the purpose of teaching people how to implement the invention concerned, or enabling the practice of invention.

In practice, this provision is implemented in the form of requirement to have a patent description, providing explanation on the manner in which the production is on an invention. Patent description is usually a description of the process in which the invention can be applied in the production process. The patent application document should provide this description. It can be in the form of text which is sometimes accompanied by drawings. Following are some examples of drawings that are normally presented related to enabling the practice of invention. Drawing (1) is an example of making a camera based the invention that is subject to the patent application. Drawing (2) is an example of describing the process of making a blood

determining the novelty of a technology. Unless the patent examiner is well informed about a previously existing identical technology, the chances are that the patent application will be granted. This may be considered as the weak point of the patent protection system.

${ }^{27}$ See Article 2 paragraph (2) of the 2001 Patent Law

${ }^{28} \mathrm{~J}$. Witherspoon as quoted in Merges, Patent Law and Policy, p. 479.

${ }^{29}$ According to the definition of invention provided for in Article 1 sub-article (2): "invention is the inventor's idea spelled out in a specific problem solving activity in the field of technology ...", where usefulness means that the invention contributes to the solution of a specific problem in the field of technology. 
pump (artificial heart). Experts in the field of technology concerned can use the description and drawings to produce the relevant product.

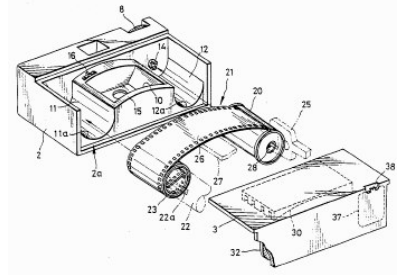

Drawing 1

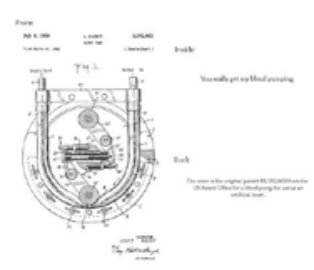

Drawing 2

Source: www.patentlyo.com; www.core77.com

Obviously, only the inventor is able to make such drawings. The description, however, can be prepared by a Patent Consultant based on the information or explanation provided by the inventor. The Patent Consultant's involvement in preparing that description is limited to technical matters related to the patent application letter, in order to ensure that the application meets certain standards for filing the patent application with the Patent Office. This is related to the substantive examination process conducted by the patent examiner. Unless the description is prepared in a standardized form, the patent examiner is likely to encounter difficulties in performing his duty.

In practice, patent description is often handled in a tricky way. It is referred to as a tricky way, because it is related to business competition. An inventor who does not wish to see his technology being imitated by other people is likely to hide his invention. At the same time, based on the patent requirements he is required to disclose information about his invention to the public. In order to accommodate both these two opposing interest, inventors often resort to certain tricks. One of these tricks is preparing the patent description in a way that makes it difficult for other people to implement it without the inventor's involvement, while at the same time convincing the patent examiner that the invention is implementable in the production process. This requires experience both on the part of the inventor as well as the Patent Consultant concerned.

Patent description is also related to the transfer of technology. The Patent Law of 2001 sets forth that a patent holder is obligated to produce the product or apply the process provided by the patent concerned in Indonesia. ${ }^{30}$ The purpose of this provision is to ensure that the protected patent can be studied by Indonesian through the transfer of technology process. By such implementation in Indonesia, the idea of patent disclosure is truly materialized. However, in reality, it is by no means easy to ask patent holder to voluntarily conduct transfer of technology. Commercial considerations are determining factor in the successful implementation of the idea of transfer of technology through the patent system.

There has been no empirical evidence so far how effective is this implementation. At the same time, there are no sanctions and implementing

${ }^{30}$ Article 17 (1) of the 2001 Patent Law. 
regulations compelling patent holders to conduct transfer of technology. On the contrary, exclusive right or the right of monopoly on technology is provided to patent holders by virtue of the provision of Article 16 of the 2001 Patent Law. These provisions are further reinforced with the provisions providing for an exemption from the obligation for patent implementation as set forth in Article 17 paragraph (2) of the 2001 Patent Law. This paragraph provides for economic consideration as a cause for exemption from obligation. If the implementation of a patent in Indonesia is not feasible, ${ }^{31}$ the obligation is no longer applicable to the patent holder. With the introduction of paragraph (2), the obligation set forth in paragraph (1) appears to be a mere 'comforting reassurance' that the 2001 Patent Law does provide for transfer of technology.

\section{Terms of protection}

Patent protection is granted for twenty years as from the filing date. ${ }^{32}$ The same provision is universally applicable all over the world as a result of the TRIPs Agreement. However, it needs to be noted that not all patent applications are accepted, hence it needs to be understood clearly that patent protection occurs only after the Patent Office grants the right.

There is a considerable lapse of time between the filing date ${ }^{33}$ and the time at which the patent is granted. Based on the provisions of the 2001 Patent Law, we can easily calculate the period of time required for a patent application to be either granted or rejected. The following table may be useful in estimating the period of time between the filing date and the date on which the patent is granted.

\begin{tabular}{l|l}
$\begin{array}{l}\text { Commencement date for announcement of application } \\
\text { meeting the requirements }\end{array}$ & 18 months as from the filing date \\
\hline Duration of announcement & 6 months \\
\hline Application for substantive examination & 36 months following the date of receipt \\
\hline Decision on granting or rejecting the application & $\begin{array}{l}3 \text { months after receiving the request for substantive } \\
\text { examination }\end{array}$ \\
\hline Filing for objection & $\begin{array}{l}3 \text { months as from the date of receiving the rejection } \\
\text { notification letter }\end{array}$ \\
\hline Commencement of objection examination & 1 months as from the date of receiving an objection \\
\hline Duration of objection examination & $\begin{array}{l}9+1 \text { months as from the date of receiving a filing for } \\
\text { objection }\end{array}$ \\
\hline Appeal to the court if the objection is rejected & 3 months as from rejection by the Appeal Commission \\
\hline $\begin{array}{l}\text { The duration of the appeal examination process at the } \\
\text { Commercial District Court + Cassation is determined by } \\
\text { the court }\end{array}$ &
\end{tabular}

Based on the above described time frame, the process from the patent application to the patent being granted can be estimated to take over six years (in

31 The Official elucidation on paragraph (2) Article 17 of the 2001 Patent Law reaffirms namely that the provisions of this paragraph (2) are intended to accommodate the economic rationality of patent implementation, as not all types of patented inventions are economically profitable if the market for the products is not proportionate to the investment made.

32 See Article 8 of the 2001 Patent Law.

${ }^{33}$ For date of receipt, refer to Article 30 paragraph (1) of the 2001 Patent Law. 
addition to the process of appeal at the Commercial District Court and the Supreme Court). At the same time, patent protection is granted only for twenty years as from the filing date, thus leaving less than fourteen years of definitive protection. However, it needs to be understood that the patent holder does enjoy protection for twenty years. How can that be the case? The answer to that question is that the commencement of protection is determined to be effective retroactively as from the filing date.

This can be practically calculated in the following way. While the patent application is still awaiting approval (it is still in process), the applicant is not yet benefiting from legal protection because there is a possibility of the application being rejected. If the application is rejected, the applicant does not obtain legal protection (no patent, no protection). However, if the patent application is granted, the commencement of protection is applicable retroactively as from the filing date. Thus, if there is any party using the invention after the filing date, at a time when the patent has not been granted yet, the patent holder can sue that party. However, the basis for the suit only occurs after there is certainty that the patent has been granted, namely after the decision for granting the patent is issued as evidenced by the issuance of a Patent Certificate. ${ }^{34}$

\section{A. Patent and nanotechnology}

As mentioned above, patent right is the right of the patent holder to the exclusive use of his innovation technology. Such technology includes nanotechnology, ${ }^{35}$ which has developed parallel to the development of science and technology.

Categorically, nanotechnology can include various cross sections among research areas as illustrated in the figure here below.

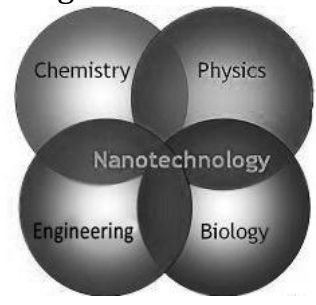

Source: www.gvsu.edu

\footnotetext{
${ }^{34}$ According to Article 57 paragraph (1) of the 2001 Patent Law, the Patent Certificate is a proof of Patent Right.

35 Nanotechnology is a science which operates at an extremely small scale, as it uses the size of a socalled nanoscale, which is approximately between 1 and 100 nanometers, or 1 to 100 billionths of a meter. There are two types of nanotechnology application. First, top-down, namely making the structure of technology increasingly smaller, until it reaches an extremely small, nanometric size. Second, bottom up, namely selecting and combining extremely small nano particles to form other materials or mechanisms. Source <http://www.wipo.int/patent-law/en/developments/nanotechnology.html>, accessed on February 182010.
} 
On its website, National Cancer Institute describe nanotechnology to include all areas of technology, "nanotechnology is being applied to almost every field imaginable, including electronics, magnetics, optics, information technology, materials development, and biomedicine". ${ }^{36}$ It can be concluded, there for, that nanotechnology has a relatively broad scope. That may be the reason why a uniform classification of inventions using nanotechnology is not yet available in the patent system, especially related to patent classification.

In October 2004, USPTO prepared a new classification for patent applications in the U.S., which subsequently became known as Classification 977. This classification includes patents (1) whose subject matter is in the scale of approximately $1-100$ nanometers in at least one dimension; and (2) that involve materials, structures, devices or systems that have novel properties and functions because of their nanoscale size. ${ }^{37}$ Nanotechnology for which patent application can filed with the USPTO under Classification 977 include the following: ${ }^{38}$

1) "nanostructure and chemical compositions of nanostructure;

2) device that include at least one nanostructure;

3) mathematical algorithms, e.g., computer software, etc., specifically adapted for modeling configurations or properties of nanostructure;

4) methods or apparatus for making, detecting, analyzing, or treating nanostructure; and

5) specified particular uses of nanostructure. The Class define "nanostructure" as an atomic, molecular, or macromolecular structure that (a) Has at least one physical dimension of approximately $1-100$ nanometers; and (b) Possesses a special property, provides a special function, or produces a special effect that is uniquely attributable to the structure's nanoscale physical size."

However, it needs to be noted that the above mentioned Classification 977 can only be used for bottom up nanotechnology. At the same time, top down nanotechnology is generally not included in Classification 977.39 This is quite understandable, as only bottom up nanotechnology contains the element of novelty and involves the element of inventive step (non-obviousness) as required under the patent protection system. Top-down nanotechnology is usually applied in scientific research which is not intended to create something new (let alone for commercial purposes); rather than that, it is only used for the purpose of pure scientific research.

An example of the application of potentially patentable nanotechnology is related to the use of gold nano-particles. Research has revealed several benefits that can be obtained by using cold with nanotechnology. For instance, NanoSpectra has successfully used gold nano-particles as drug-coated to channel drug molecules to cancer cells. This invention called Auroshell ${ }^{T M}$ can destroy cancer tissues without

36 <http://www.cancer.gov/aboutnci/servingpeople/cancerstatistics/snapshots>, accessed on March 13, 2011.

${ }^{37}$ Patenting Nanotechnology - an Overview of The Current Climate and Explanation of Classification 977. Refer to <http://www.azonano.com/Details.asp?ArticleID=1379>, accessed on February 18, 2011.

38 Mohamad Mova Al'Afghani, Patent Classification for Nanotechnology, <http://nanolaw.alafghani.info/2006/03/patent-classification-for.html>, accessed on February 18, 2011.

${ }^{39}$ About the bottom-up and top-down approach, refer to the previous footnote. 
damaging the surrounding tissues by combining the physical and optical characteristics of gold using laser. This invention is reportedly highly stable, accurate and non-toxic hence it does not have side effects. ${ }^{40}$

The non-obviousness in this invention is related to, among other things, the high level of accuracy in the use of medicine. In general, drug molecules are unable to distinguish normal organ cells and cancer cells, and so the use of a drug can cause side effects which can be actually more dangerous than the cancer itself. Auroshell ${ }^{\mathrm{TM}}$ is the result of the research looking for the best ways of ensuring that the drug molecules are able to reach the targeted cells without damaging healthy cells in the body. The gold nano-particle has proved that it can offer such solution. ${ }^{41}$

Reportedly, gold nano-particles are also extremely useful in the current computer era. They are used high density data storage. With the development of computing and portability, there is an increasing need for storing data in portable, mini instruments, and of course at an affordable price. A solution to that problem has been provided in the the form of DVD or flashdrive which are managed on the basis of nanorod gold nanotechnology with a capacity over 10 TB $(10,000$ GB). Such an extremely high capacity is obtained from the application of gold nanorod which has the capacity of reading all of the possible various polarities of light at particular wavelengths, as well as from the three-dimensional frequency modification causing increasingly larger polarities, thus considerably increasing its capacity. ${ }^{42}$

This article will not discuss nanotechnology itself, as it exceeds the author's authority. The purpose of this article is to explore the potentials of patent as a legal instrument for providing protection to researchers who are successful in coming up with an invention which can be potentially useful by using nanotechnology. Basic question is how to apply for a nanotechnology patent? Who is going to conduct substantive examination considering the sophistication of this technology, which may not be accessible to local patent examiners? ${ }^{43}$ Is the Indonesian Patent Office ready to receive patent applications for nanotechnology?

According to Joff Wild, either of the following two equally unfavorable things is likely to occur if the Patent Office is not ready, but is compelled to receive nanotechnology patent application: (1) delayed protection which is of course unfavorable to the applicant, or (2) controversial granting of patent due to lack of understanding on the part of patent examiner, hence the decision for granting the

40 Gold and Nanotechnology, <http://www.kaskus.us/showthread.php?p=369747285>, accessed on February 18, 2011.

${ }^{41} \mathrm{Ibid}$., This is what we call in the patent system as the inventive step, namely the element of nonobviousness in the use of gold nano-particle in medicine technology.

42 Ibid.

${ }^{43}$ This statement was made by Joff Wild speaking about the preparedness of the USPTO to examine patents. Following is a quotation by Wild of an opinion expressed by Alan Marty (JP Morgan \& Partners), "I have heard from both investors and nanotech executives that take a long time with applications ask a lot of questions and generally slow down the value creating process. The implications can be damaging. The longer it takes to get the patents issued, the more of a negative impact it is going to have on company valuations. And that will make it harder to attract funding." How would a developing country, such as Indonesia, deal with nanotechnology patent applications? The chances are that patent examiners may not just as yet be well prepared and well trained to anticipate the task. See Joff Wild, "Patent Challenges for nanotech Investors", Intellectual Asset Management 
patent is not based on his understanding of the requirement for the patentability of the invention.

The issue of preparedness of Patent Offices in the developing countries, such as Indonesia, is a hurdle in the implementation of patent protection in such countries. As Jim Myers from the Law Firm Kilpatrick Stockton has stated, the USPTO itself has also been facing an overwhelming number of nanotechnology patent applications. ${ }^{44}$ If a Patent Office such as the USPTO is overwhelmed with nanotechnology patent applications, one can easily how the situation would look like if a similar overflow of nanotechnology patent applications occurred in Indonesia (Directorate General of Intellectual Property Rights, Ministry of Law and Human Rights). After all, the not very distant future U.S. investors may wish to apply for patent in Indonesia once they start marketing their nanotech based products in Indonesia. It is in such context that universities need to take a maximal role.

\section{B. Nanotechnology and the role of universities as education and research}

\section{institutions}

Universities have an extremely broad opportunity to play a role in the development of nanotechnology. There are at least three main roles related to the Tri Darma [Three Basic Duties] of University, namely as follows:

1) Prepare reliable human resources mastering science and technology, including nanotechnology. This role is in line with the role of education and teaching as the first duty of a university.

2) Conduct top-down nanotechnology research as part of the role of research in developing science and technology. This role is in line with the second duty, namely research and the development of science of technology.

3) Conduct bottom-up nanotechnology research to produce products benefiting the human kind. This role is in line with the third duty, namely serving society. By contributing to the community by providing products that benefit society, the university concerned can tell the world that it has properly implemented its role in contributing to the human kind. This role can also potentially bring economic benefit for the university concerned, as the inventions resulting from research can be commercialized through the patent system.

\section{How to implement such role in the real world?}

The university can implement the first and second duty simultaneously. In order to enhance integrity and quality in teaching technology, the university can develop research in nanotechnology, the result of which can be used as teaching reference materials for students. The statement of being a research University can be materialized in the form of policy supporting endeavors for nanotechnology and nanoscience development. In this context, the university does not need to be concerned about the fact that nanotechnology patent development is yet to be accommodated in

\footnotetext{
${ }^{44}$ Refer again to Wild, Ibid.
} 
Indonesia. After all, top-down nanotechnology is note intended for commercial purposes, only for the development of science itself.

In the context of the role related to the third duty of the university, particularly in connection with the development of bottom-up nanotechnology, there is an interesting provision in the United States known as the Bayh-Dole Act 1980. Although this act is applicable only in the United States, it may be interesting to study and apply its philosophy in the world of education in Indonesia, particularly at universities. According to the Bayh-Dole Act 1980, universities can hold patent for inventions as a result of research funded by the state. This law has encouraged the development of research at universities, as it provides a vast opportunity to the universities to obtain patent, even though research is funded by the State. ${ }^{45}$

One of the Indonesian universities which has opened up the opportunity to researcher within its environment is Universitas Indonesia. This university has a system which allows a lecturer to conduct research at the expense of the university. The greatest reward to the researcher concerned is when he is able to come up with a patentable invention. ${ }^{46}$ This system is rather similar to the system developed based on the Bayh-Dole Act 1980 applicable in the United States.

If universities were assume a role in developing nanotechnology which is useful not only in the academic context, but also useful for the community and the economically beneficial to the universities concerned, ${ }^{47}$ we must think about developing a system for university technology transfer. ${ }^{48}$ There are several ways for developing such system, and one in particular deserves particular consideration, namely the establishment of Technology Transfer Licensing Office (TTLO) within the university's organization. ${ }^{49}$

The following working mechanism needs to be considered with the aim of maximizing the achievement of the purposes of TTLO establishment:

${ }^{45}$ See Bahven N. Sampat. et. al., Changes in University Patent Quality After The Bayh-Dole Act: A Reexamination, westlaw@westlaw.com

46 The reward intended here is in the form of scoring with a high score, of course in addition to certain economic benefit which can be potentially obtained from the commercialization of the patent concerned.

${ }^{47}$ Economic benefit can be obtained by commercial exploitation through the patent system of any new technology developed by the civitas academica of a university.

48 This system has been developed at Waseda University in Japan. The author has become award of this during the 6-moth research he conducted in Japan from October 1999 through the end of March 2000. For the development of the university technology transfer system in Europe, refer to Joaquin M. AzagraCaro, Recognising the Value of Business Patents with the University Inventors, Directorate-General of Research, European Commission, 2009. See also again, Reichman, University-Industry Collaboration.

${ }^{49}$ This proposal may indeed not be entirely new. Some time ago, through the CyberLaw Journal Published by Faculty of Law, the author had made the same proposal. At the same time, apparently the current Directorate of Partnership and Business Incubator at Universitas Indonesia also deals with more or less the same issues. 


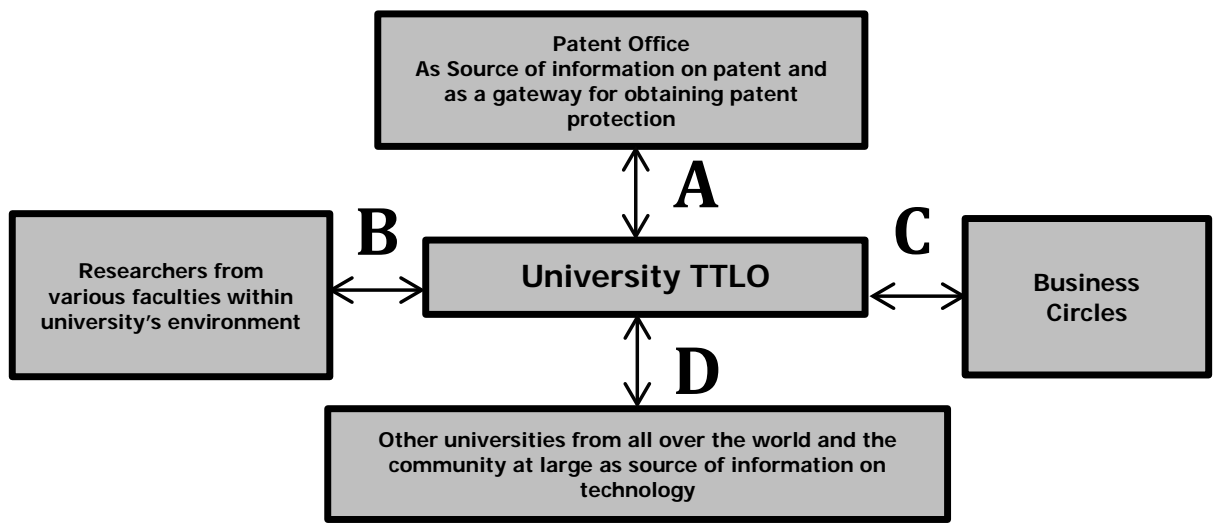

The work flow based on the above diagram can be described as follows:

1. A: TTLO helps researchers to access data prior to starts in cooperation with the Indonesian Patent Office enabling them to access patent information coming from Patent Offices from all over the world. Such access enables researchers to obtain data from Patent Offices in the world about technology (including nanotechnology) developed and protected as a patent.

2. B: Data on the technology information is conveyed or made available to researchers at the universities, hence researchers will be able to avoid duplication in research. In addition to that, it will also help researchers in understanding and identifying technologies that are still open for further development. This will be extremely useful to facilitate researchers in selecting research activities that are needed, not only for academic development itself, but also for the purpose of economic benefit obtained from the research concerned.

3. C: TTLO engages in cooperation with business circles. Through this network, TTLO is able to access information on technology trend demands in the industry market. At the same time, the TTLO can also provide information about research development implemented by researchers at the universities.

4. D: Technology information can be obtained from any source whatsoever, including through the interuniversity link which can be developed among universities. Information can also be accessed from various sources which are not limited to institutions. Researchers can of course access information from their own sources. In this context, TTLO with its technological sets of equipment can give valuable contribution by assisting researchers to access technology through the system built by TTLO. Ideally, the TTLO could provide the space needed to access technology. Such a space is not intended to be the rival of a library (which is also a source of information). More specifically, the TTLO can make technological 
set of equipment available to facilitate access to sources of information, including in the field of nanotechnology.

5. A: Once researchers come up with patentable inventions, the TTLO can acts as agent in the process of filing a patent application with the Patent Office. For that purpose, the TTLO have to be equipped with necessary resources, one of them being patent drafters and patent attorneys, who will represent the inventors in patent applications.

6. C: The TTLO can also act as an agent in marketing inventions that are in the process of being patented or that have already been patented among industry circles. In this context, the TTLO must be equipped with a division handling Intellectual Property Valuation and Management related issues.

7. A, B, C, D: The TTLO can build an information network in the field of technology by providing information in the form of patent map. Such information is utmost significance in the context of investment allocated by the industry for the Research \& Development (R\&D), particularly in the context of ensuring that their investment is linkable with the market demand and the availability of related technology. The patent map is also useful for researchers in planning their research. At the same time, in the context of inter university link, the patent map can serve as an important source of information among education and research institutions, particularly in Indonesia, hence the TTLO will eventually become an institution that is needed not only in university circles, but also in much broader circles.

In view of the above described ideas, the TTLO needs to put in place organizational infrastructure, complemented by the appropriate hardware and human resources, in order to ensure that the activity areas described here below will be able to function as expected. The abovementioned organizational infrastructure includes the following, among other things:

1. Information Technology Division to deal with issues of information access and processing;

2. Intellectual Property Valuation and Management Division to deal with Intellectual Property Rights management in the context of business;

3. Legal and Licensing Office Division to deal with patent applications and protection, and handle invention commercialization projects based on licensing agreements with industry circles;

4. Partnership Division which will build and maintain relationships between the TTLO and third parties, particularly related to researchers or academic circles (including other universities in Indonesia, as well as overseas) and industry circles, with Government Agencies, including the Intellectual Property Rights Office, the Ministry of Industry, Trade, Telecommunications, and others, as well as institutions such as WIPO, and others.

This proposal is of course very open ended, meaning that it has a high level of flexibility in its implementation by any university, with due regard and adjustment to the available capacities and resources. To illustrate the point, the TTLO's role can be 
materialized by integrating it into the organization of the existing Directorate for Research and Community Service (DRPM/Direktorat Riset dan Pengabdian Masyarakat) and the Directorate for Partnership and Business Incubator (DKIB/Direktorat Kemitraan dan Inkubator Bisnis). While at the university level, Universitas Indonesia can encourage its faculties to untilize the abovementioned network developed by the TTLO.

\section{Conclusion}

In the context of nanotechnology development at university, the role of the university can be implemented through the TTLO, particularly in an effort to build a bridge for bottom-up nanotechnology for commercial purposes. At the same time, in the context of the development of science itself, particularly top-down nanotechnology, the university or its faculties play perhaps a somewhat more dominant role. However, the TTLO can certainly help in facilitating the flow of information needed by each faculty or department in developing the area of science concerned. Eventually, there will be an increasingly significant link between the patent system and the university's role in the development of nanotechnology.

It is the author's hope that this article will serve as a source of inspiration and motivation for the University's civitas academica for using the patent system, particularly for the purpose of teaching, research and service to the community. In the context of nanotechnology, this article will hopefully serve as a source of inspiration for researchers in this particular area encouraging them to consider the patent system, at least in the context of considering the possibility of using their inventions in an economically beneficial way. As for universities in Indonesia, it is expected that this article will bring an impetus in the formulation of policies ensuring that the jargon research university is actually materialized. Amien.

\section{Bibliography}

Aldous, William. et. al., The Law of Patent. London: Sweet \& Maxwell, 1982.

Azagra-Caro, Joaquin M. Recognising the Value of Business Patents with the University Inventors, Directorate-General for Research, European Commission, 2009.

Al'Afghani, Mohammad Mova. Patent Classification for Nanotechnology, http://nanolaw.alafghani.info/2006/03/patent-classification-for.html

Kenney, Martin. Reconsidering the Bayh-Dole Act and the Current University Invention Ownership Model, a paper downloaded from http://www.sciencedirect.com/science/article/pii/S0048733309001516

McKeough, Jill. et. al., Intellectual Property: Commentary and Materials, 4th ed., Lawbook C., 2007.

Mergers, Robert Patrick. Patent Law and Policy: Cases and Materials, Virginia: Michie, 1997.

Richman, J. H., "University-Industry Collaboration: The United States Experience", WIPO Conference Paper, June 23, 2005.

Sampat, Bhaven N. et. al., Changes in University Patent Quality After the Bayh-Dole Act: ARe-examination,westlaw@westlaw.com. 
Wild, Joff. "Patent Challenges for Nanotech Investors", Intellectual Asset Management, September/October 2003.

Patenting Nanotechnology - an Overview of The Current Climate and Explanation of Classification 977. <http://www.azonano.com/Details.asp?ArticleID=1379>.

Gold and Nanotechnology, <http://www.kaskus.us/showthread.php?p=369747285>. The Strassbourg Agreement Concerning The International Patent Classification 1971. 